\title{
The Ability of Coco Fiber Material in Reducing Heat as An Insulation of Building Walls on Accepted Temperature Level
}

\author{
Kemala Jeumpa ${ }^{1}$, Selamat Triono ${ }^{2}$, Rusnardi Rahmat ${ }^{3}$ \\ Lecturer of Faculty of Engineering, State University of Medan, Indonesia ${ }^{1,2}$ \\ Lecturer of Faculty of Engineering, State University of Padang, Indonesia ${ }^{3}$
}

\begin{abstract}
This paper was purposed to determine the ability of coco fibers in reducing heat as a wall covering solution with different temperature levels. For the fulfillment of thermal comfort in buildings requires engineering, knowledge and skills and innovation. One way to reduce hot air in the room can be done through walls, thereby reducing the use of air conditioning. The walls need protection and solar heat absorbers that can make the room inside the building have thermal comfort. Based on this, research needs to be done on natural ingredients that can function to reduce heat. Tests carried out on coconut fiber and fiber-free materials. Material without fiber and coco fiber is $2 \mathrm{~cm}$ thickness of each. This coco fiber material is coated with a mixture of cement that also functions as a fiber adhesive. In this case, testing is conducted by applying heat of $60^{\circ}$ Celsius and $40^{\circ}$ Celsius to one side of the fiber and measuring the temperature that occurs on the other side of the fiber. The test results found that there was a significant difference between the heat temperature supplied and the heat temperature measured on coco fiber. The higher the temperature is received, the greater the heat that can be absorbed. This shows that coco fiber material has the ability to reduce heat at high enough heat as a wall covering against solar radiation.
\end{abstract}

Keywords: coco fiber, insulation, building wall, cement, reduce heat

\section{Introduction}

Sunlight is the main source of heat in the building, the heat of sunlight will mainly enter the room through the media of roof and wall. About $83 \%$ of the sun's heat in the form of infrared rays on the roof and building walls are absorbed and emitted into the room by radiation, conduction and convection. In humid tropical climates, the building coating is a building element that must be able to protect the occupants from the sun's heat, also reducing the radiant heat forwarded into the building. Therefore one of the functions of the building coating is to control or reduce the heat load from solar radiation into the building (transmission). The entry of solar radiation into the building can be through a vertical cover that is a wall or a horizontal or sloping cover that is roof. Cooling the space in this way is classified as passive cooling system that relies heavily on air movement as a hot carrier medium in the morning to late afternoon to reduce room's temperature.

Global warming causes the warming of the earth's temperature so that the use of air conditioner in the room is also increase as the need for comfortable room condition is also higher. This will increase the energy use of the earth and increase the contribution of rising earth temperatures and greenhouse effect. From the research of previous research also revealed the 
fact that $50 \%$ of the energy absorbed in a building is only consumed by refrigerators only, therefore $30 \%$ of the total energy required by a country is usually used in housing. This figure is from conditions in developed countries that are more manageable, for in developing countries this figure will not be smaller even believed otherwise. If this fact not handled strategically, will be a terrible impact on sustainable nation development. Based on these factors, it is need to be balanced with the existence of building innovations that can save energy and environmentally friendly, as has been developed in several countries.

The heat on the wall will propagate into the room so the room becomes hot. Walls need protection and dampening from the sun's heat so that indoor space will not heat up. Therefore one way to inhibit heat from outside the room can be done through the wall. Non-heated rooms can reduce the use of air conditioning. By reducing the use of air conditioner means to save energy and also save the earth and the environment.

Environmental awareness can be realized with the use of materials derived from nature as a form of energy conservation and environmental protection. For example, coconut coir (coco fiber), is one of the wastes that has not been fully utilized in Indonesia. The amount of coco fiber capacity produced from coconut harvest annually in Indonesia is quite large where coconut fiber is a large part of coconut fruit, which is $35 \%$ of the total weight of coconut.

Based on this matter, it is necessary to do research on natural materials that can reduce heat. The problem that arises in this study is how is the potential of coconut fiber material based on the character of thick fiber as insulation to reduce heat. This research was conducted with the aim to know the potential of coco fiber that later can serve as a wall covering the building to reduce heat from outside.

\section{Research Method}

The material in this study consisted of several character for coco fiber material, namely 1 $\mathrm{cm}, 2 \mathrm{~cm}$ and $3 \mathrm{~cm}$ coated with a cement mixture. The other materials are mixtures of cement and sand commonly used as wall plaster material. The process of making the material can be shown in Figure 1 below.

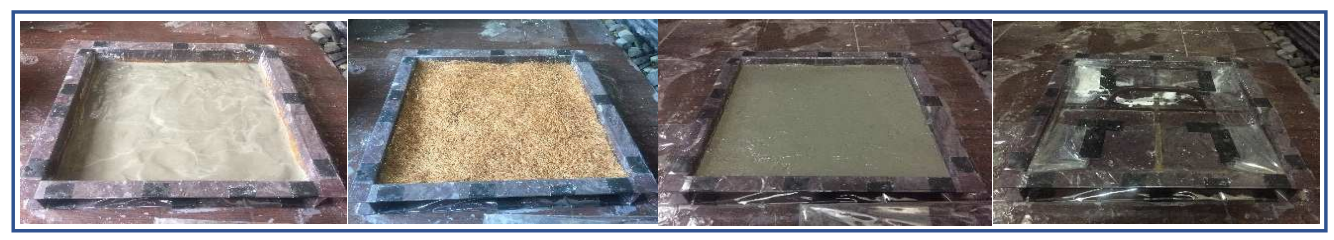

Fig.1 The process of making fiber test material

This research approach is based on experiments to determine the ability of coconut fiber to reduce heat at high temperatures. In this case, test is conducted by comparing the two temperature tests. After the fiber and cement are good enough to bind and harden then be tested. In this case testing by applying heat to one side of the fiber and measuring the temperature that occurs on the other side of the fiber. The same tests and heat treatments are also carried out on fiber-free materials. The heat given is $35^{\circ} \mathrm{C}$ and $60^{\circ} \mathrm{C}$ for 120 minutes. Tools to measure the temperature that occurs in the material used sensors that are connected to the computer and can be read on the monitor screen. 


\section{Results and Discussion}

Research on innovations related to environmentally friendly buildings to answer the phenomenon of global warming has been done by some researchers in research on building materials for walls that can reduce heat among them is, who conducted research on lightweight concrete panels focus on the pearlite as a mixture of concrete panels that can serve as a heat insulator [1]. Another research on the mortal mix materials focus on the utilization of Pumice Breksia as the main ingredient of instant mortar as a heat reducer. While another research conducts a hot conductivity study between Styrofoam and rice coir and focuses on measuring the comparison between Styrofoam particle board composition with rice coir particle board composition as a good material for heat insulators. Similarly, several studies conducted by foreign researchers on building materials for a wall capable of muffling the heat among them [2], who conducted a study of the wall of the building that focused on the addition of retroreflective material on the wall, which can improve the temperature of the building by reflecting solar radiation back in the opposite direction. Furthermore, another research conducted a study on building walls with a focus on determining the thermal conductivity of cement reinforced by periwinkle shells (sea shells) used as construction materials [3]. Meanwhile, another conducted a study of building walls with a focus on hygrothermal behavior of plant-based insulation products to assess their impact on energy performance in buildings, predict indoor climatic conditions, and prevent unexpected degradation risks [4].

Coconut fruit composed of fibers called fiber that serves to protect the hard part called the shell, serves to protect the seeds that are only protected by the membrane attached to the inner side of the shell, there is a liquid containing many enzymes called coconut water, and solid phase settles on the wall of the shell along with the growing old fruit called coconut meat. It can be concluded that the coconut coir is part of the coconut that protects the inside of the coconut from the outside including from the heat of the sun. Based on this coconut coir is estimated to have the potential for heat insulation, because it is necessary to research the character of coco fiber as a building wall coating to reduce heat.

This study compared the potential character for thick the material of coco fiber with the material without fiber. Test results can be shown in the graph in the following figure.

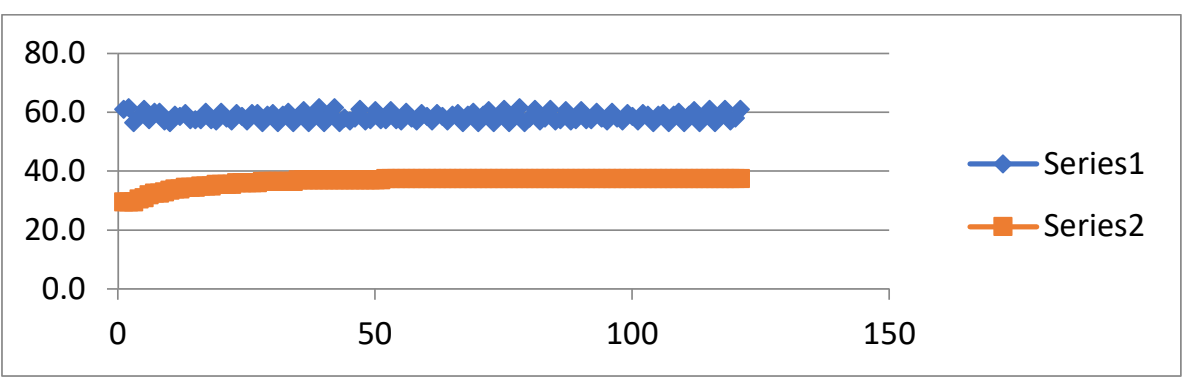

Fig. 2 The results of the test material without fiber with a temperature of $60{ }^{\circ} \mathrm{C}$

The graph in Figure 2 shows the results of the test material without a coir. The Y axis of the series line 1 shows the amount of heat applied to one side of the material expressed in Celsius, while the series 2 indicates the amount of heat measured on the other side of the material. The $\mathrm{x}$ axis shows the length of time during the test expressed in minutes. The results obtained from the graph show that when given the heat of $60{ }^{\circ} \mathrm{C}$ for 120 minutes. Then the measured temperature on the other side of the material without a coat ranges from $38{ }^{\circ} \mathrm{C}$. 


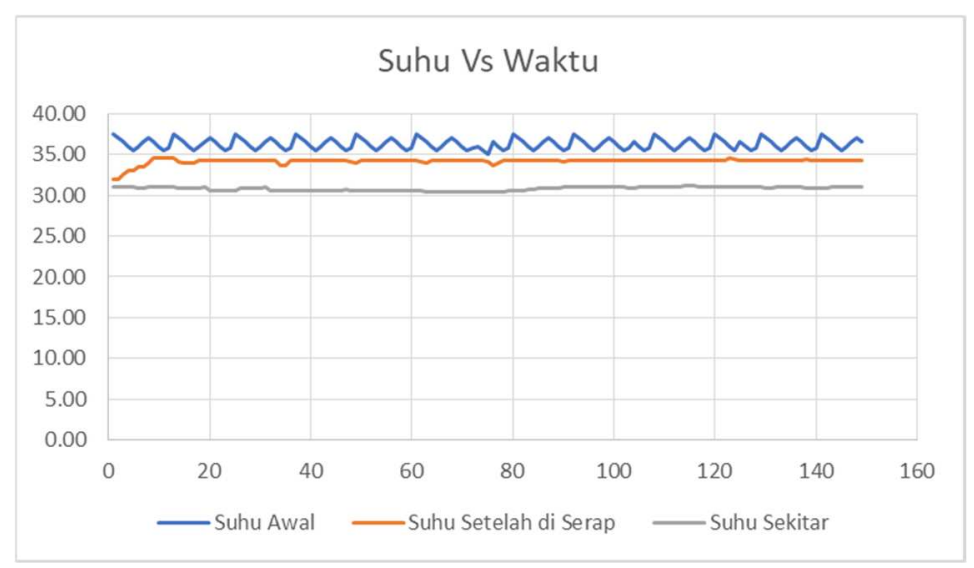

Fig.3 The results of the test material without fiber with a temperature of $35^{\circ} \mathrm{C}$

The graph in figure 3 shows the results of the test material without fiber. The Y-axis of the series 1 line shows the amount of heat applied and measured on one side of the material expressed in Celsius, while series 2 shows the amount of heat absorbed by the material measured on the other side of the material, next the series 3 shows the measured temperature in the environment around the test. The X-axis shows the length of time during the test expressed in minutes. The results obtained from the graph show that when given the heat of 35 Celsius for 120 minutes that the temperature measured on the other side of the material without fiber ranges from $34.5^{\circ} \mathrm{C}$.

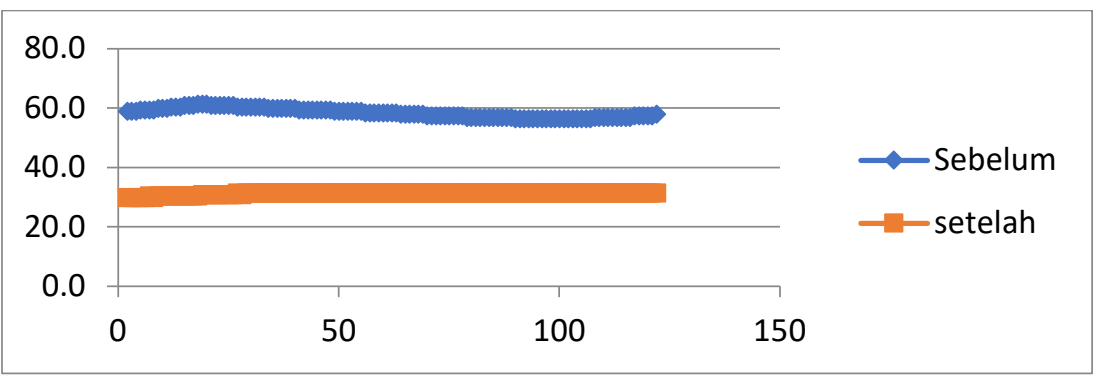

Fig. 4 The test results of fiber materials $2 \mathrm{~cm}$ with a temperature of $60{ }^{\circ} \mathrm{C}$

The graph in figure 4 shows the test results of the fiber material. The $\mathrm{Y}$ axis of the series line 1 shows the amount of heat applied to one side of the material expressed in Celsius, while the series 2 indicates the amount of heat measured on the other side of the material. The $\mathrm{x}$-axis shows the length of time during the test expressed in minutes. The results obtained from the graph show that when given the heat of $60{ }^{\circ} \mathrm{C}$ for 120 minutes. The measured temperature on the other side of the fiber material is $32{ }^{\circ} \mathrm{C}$. 


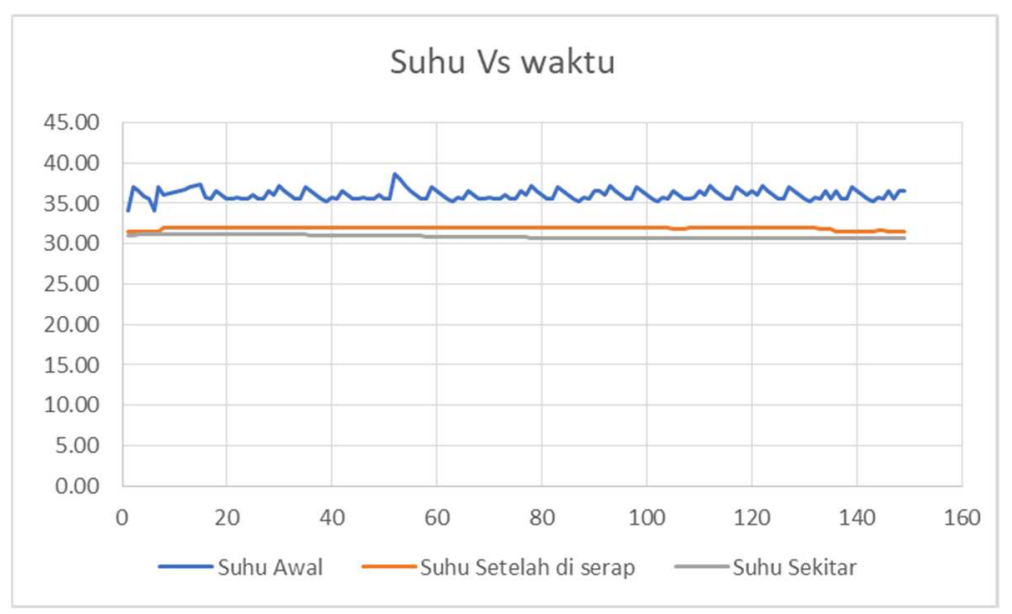

Fig. 5 The test results of fiber materials $2 \mathrm{~cm}$ with a temperature of $35^{\circ} \mathrm{C}$

The graph in figure 5 shows the test results of the fiber material. The Y-axis of the series 1 line shows the amount of heat applied and measured on one side of the material expressed in Celsius, while series 2 shows the amount of heat absorbed by the material measured on the other side of the material, next the series 3 shows the measured temperature in the environment around the test. The $\mathrm{X}$-axis shows the length of time during the test expressed in minutes. The results obtained from the graph show that when given the heat of $35{ }^{\circ} \mathrm{C}$ for 140 minutes that the temperature measured on the other side of the material of fiber $2 \mathrm{~cm}$ ranges from $31.5{ }^{\circ} \mathrm{C}$.

From the results of experiments conducted in this study showed differences in temperature measured between coco fiber and without fiber. A significant difference also occurs between the measured temperature of the coco fiber material when it receives a different temperature level of heat. From the comparison of the temperature level shows that the higher the level of heat received, the greater the heat can be reduced by fiber material. The results of this study may still be far from perfect because the test equipment used is still limited.

\section{Conclusions}

From the ratio of temperature received and measured on coco fiber material, it can be concluded that coco fiber material has the ability to reduce heat so that it can be used as a wall covering solution to solar heat radiation from outside. Based on the experimental results the higher the heat temperature received the greater the heat that can be reduced. 


\section{Acknowledgements}

I thank to Mr. Prof. Selamat Triono and Mr. Rusnardi Rahmat, Ph.D as promoters and copromoters. This research will later be presented to those with an interest in buildings and observers of energy-efficient buildings. Thank you countless to those who helped in this research.

\section{References}

[1] Sari Ayu Yuswita dkk, Pembuatan Panel Beton Berbasis Perlit dan Aplikasinya sebagai Insulator Panas, Jurnal Ilmu Pengetahuan dan Teknologi, Volume 29, Mei (2011).

[2] Meng Xi, and friends, Effect of retro-reflective materials on building indoor temperature conditions and heat flow analysis for wall, Energy and Buildings Journal. (2016).

[3] Omubo-Pepple V.B, Opara F.E and Ogbonda C, Thermal Conductivity of Reinforced Cement Stabilized Lateritic Brick, Journal of Engineering and Applied Sciences 5 (2): 178-180, 2010 ISSN: 1816-949X. (2010).

[4] Samuel Dubois, and friends, TemperatureAnd MoistureStorageIn Crop-Based Materials: Modelling A Straw Bale Wall Subject To A Thermal Shock, Journal of Building Physics. (2015).

[5] Fadhil Md Din Mohd, and friends, Investigation of Heat Impact Behavior on Exterior Wall Surface of Building Material at Urban City Area, Journal Civil \& Environmental Engineering. (2012)

[6] Irwan dkk, Pengaruh Penambahan Serat Sabut Kelapa (cocofiber) Terhadap Campuran Beton Sebagai Peredam Suara, Journal of Civil Engineering, Building and Transportation, volume 1 nomor 1 Maret, (2017)

[7] Irwan Yusril, Pengembangan Serat Sabut Kelapa Untuk Pembuatan Papan dengan Berbagai Jenis Matrik: semen, gypsum dan tanah liat, Institut Teknologi Nasional

[8] Jeumpa Kemala, The Potential Utilization of Natural Materials as a Wall Covering of The Building in Heat Reduction, IOP Conf. Series: Materials Science and Engineering 523 (2019) 012040 doi:10.1088/1757-899X/523/1/012040 (2019).

[9] Peraturan Menteri Pekerjaan Umum dan Perumahan Rakyat Republik Indonesia NOMOR 02/PRT/M/2015, Tentang Bangunan Gedung Hijau.

[10] Subiyantoro Heru, Pengelolaan (Elemen) Selubung Bangunan Dalam Konsep Arsitektur Keberlanjutan, Artikel Ruang Arsitektur (2008).

[11] Yao Jian, Yan Chengwen, Effects of Solar Absorption Coefficient of External Wall on Building Energy Consumption, International Journal of Civil, Contstruction and Architectural Engineering, volume 5 nomor 4, 2011 (2011). 